\title{
THE ROLE OF SOCIAL MEDIA AS A BUSINESS MARKETING EFFORTS ONLINE IN ONLINE SHOP NITHALIAN COLLECTION
}

\author{
Puji Muniarty ${ }^{1 *}$, Nur Fetiningsih Syaframis ${ }^{2}$, Novitasari Devi ${ }^{3}$, \\ Khaerunnisa ${ }^{4}$, Azizah Sarifatul Nuraini ${ }^{5}$, Ahmad Maulana ${ }^{6}$ \\ Program Studi Manajemen Sekolah Tinggi Ilmu Ekonomi (STIE) Bima \\ Email : puji.stiebima@gmail.com
}

\begin{abstract}
This research method uses a qualitative descriptive method which aims to determine the Role of Social Media as an Online Shop Business Marketing Effort. This research uses a descriptive research approach using a qualitative approach. The research subject is the Nithalian Collection Online Shop Seller who is asked to provide information about a fact or opinion. The results in this study are in accordance with the research that the researchers conducted by following the nithaliancollection on Facebook. Nitalian Collection itself sells products ranging from make-up to robe under its own brand and other brands. What attracts the attention of this research is that social media from Nithaliancollektion is very thematic and neat, this is one of the factors that will influence enthusiasts of online shop to shop through social media. What's more interesting is that Nithaliancollection always reviews its merchandise in detail in the form of videos and photos on the Facebook-story, a good form of marketing effort made by Nitalian Collection is to write clearly in the bio description. Judging from social media nithaliancollektiondi, it is proven that social media is now very influential in making online shops. However, the online shop's social media must also be very well organized, have an attractive theme, and be consistent in order to attract customers to buy goods at the online shop. Online business is indeed much easier and cheaper than opening a regular store, in terms of business capital, it can save some funds.
\end{abstract}

Keywords: Internet, Social Media, Social Media Marketing, Online Shop

\section{INTRODUCTION}

Current information supports the development and information that will be obtained by the community. The community as connoisseurs of technological advances has the character to try out today's competitive technological products, communication today is mostly done indirectly, through one of them, namely smartphones. Today's smartphone users have increased drastically because the modern market guides the use of applications connected to the internet. The internet is an innovative way of conducting company activities to enter markets in cyberspace, known as electronic business (e-business) and electronic commerce (e-commerce).

The current condition is an opportunity to take advantage of the internet, especially in expanding products or services globally without time constraints and te, pta. One of the most widely used marketing concepts is E commerce through social networking. According to Wong (2010) e-commerce is the process of buying and selling and marketing goods and services through electronic systems, such as radio, television and computer networks or the internet, based on data from the Indonesian internet service providers association (APJII) stated that in the period 2019-second quarter 2020 internet users were around $86.69 \%$ of the total population of Indonesia. 
Currently, the progress of social media has become a necessity which always facilitates our affairs in addition to other effects, that's why social media have an impact on all different sects penjualan with traditional angel. Social media actually serves as a social media and interaction and attracts other people to view and visit links that contain information and can also be the most mid-priced and inexpensive marketing media. This is what ultimately attracts business actors to do so as a means of interactivity, service, building communication with widows and candidates slowly and is used as a means of selling and buying products online.

Buying and selling online through social media such as Facebook, IG, BBM, Twitter, and so on. In fact, it has mushroomed in Indonesia and has been known by the community to smell it. Buying and selling online has penetrated many people who are familiar with electronic media and have spread all over the world, especially in the city of Bima. One of the oll shops in the city of Bima is the Nathalian Collection which deals with products or services using facebook. The results of a survey conducted by researchers in online sales found problems and obstacles, namely consumers' lack of understanding of the use of social media, constraints on internet networks, and less strategic domination of places. So this is what motivates the researcher to raise the title of the research, namely the Role of Social Media as anBusiness Marketing Effort Online at the Online Shop Nithalian Collection.

\section{Internet}

According to Ahmadi and Hermawan (2013: 68), the Internet is a global communication network that connects all computers in the world even though they have different operating systems and machines. According to Termas Media, an interconnection network (internet) is a global system of all connected computer networks.

It can be concluded that the internet is something that can connect various hardware (hardware) with a network that has different operating systems and applications.

\section{Social Media}

Eisenberg (Pakuningjati, 2015: 6) concludes that social media is more effective and easily understood as definitionan online platform for interacting, collaborating and creating or sharing various kinds of digital content.

So, it can be concluded that social media is a means to interact between users to make it easier to get fast and complete information.

\section{Social Media Marketing}

H. Abu Rumman (2014) social media marketing is a marketing strategy used by business people to become part of a network with people via the internet or online.

Social Media Marketing is a marketing strategy that uses a network which requires users, hardware and the internet.

\section{Online}

Business Online business is a business that is run online using the internet network, while the information to be conveyed or sold usually uses the media of a website or application. Online business has big prospects in the future, because now almost everyone wants practicality and convenience in fulfilling their daily needs. (Majda, 2015) The conclusion of the online 
business itself is a business which is run online with the help of an network internet and users and hardware.

\section{Online Shop Online}

shopping (online shopping) is a process where consumers directly buy goods, services and others from a seller in an interactive and real-time manner without an intermediary media via the Internet (Mujiyana \& Elissa, 2013)

Online Shop is a process purchase of goods or services via the internet online without having to meet in person.

\section{RESEARCH METHOD}

\section{Types of Research This}

Type of research uses descriptive research methods. According to Sugiyono (2012: 29), is a method that serves to describe or give an overview of the object under study through data or samples that have been collected as they are, without analyzing and making generally accepted conclusions.

\section{Data Collection Techniques Data}

Collection techniques that will be used by researchers in this study are:

\section{Observation}

Observation is used to clearly observe a situation how consumers are directly involved as buyers by ordering several products found at the Nitha Collection store.

\section{Interview}

Interviews are used to find out or get information from related sources, so that the data needed by researchers can be obtained through interviews in an oral question and answer session. In order for the interview to run smoothly, the writer should prepare questions about the research to be studied.

\section{Documentation}

Documentation is used as a print that is useful to find out evidence of information about the research under study.

\section{Samples}

In the study, namely the people who make purchases of products or services at the Nithalian Collection.

\section{Data analysis techniques}

In this study, data analysis techniques were direct and structured interviews with the owner and informants from the Nithalian Collection. By analyzing data technically, analyzing data in a 
descriptive manner, the meaning of the data is presented through words and interviews directly to the source. After the data is collected, it will be obtained and the data processing begins with data reduction from the data obtained from the research, then collecting the data from the results of the reduction of the data obtained in the research after the results of presenting the food data are carried out by drawing conclusions.

\section{RESULTS AND DISCUSSION}

Social Media

In accordance with the research conducted by the researchers following the Nithaliancollektion on Facebook, which sells MakeUp to gamis with its own brand and other brands. What attracts the attention of this research is that social media from the Christian collection is very thematic and neat, this is one of the factors that will influence enthusiasts of online shop to shop through social media. Below is the Nithaliancollektion social media account.
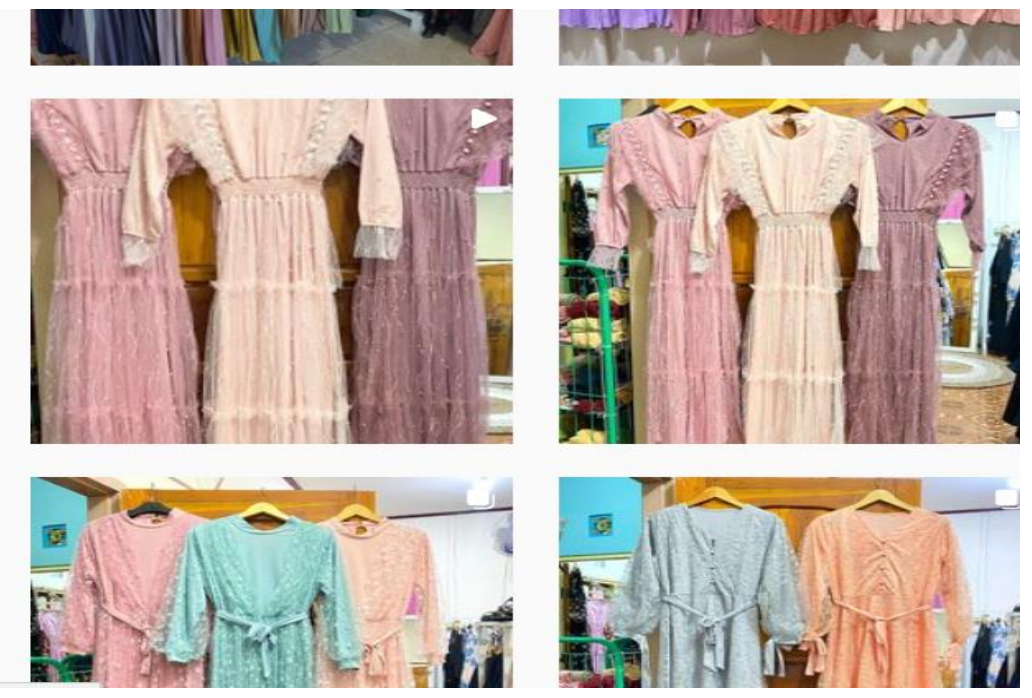

This is a form of marketing through social media that is well done by the Nithalian collection, which is eaten by them selling gamis whose prices match their pockets on Facebook. So that it will attract Facebook users. So that it attracts Facebook users to follow their Facebook so that it now has 4,987 followers, which of course will be very profitable in the marketing of its merchandise. The Nithalian Collection uses social media because social media is easier to attract the attention of buyers, besides that, the use of social media for marketing is greater than placing advertisements in other mass media.

\section{Online Shop Marketing at the Nithalian Collection}

One form of good marketing that is done by the Nithalian Collektion is to write clearly in the bio description the location, contact points, and some important things that the followers of the Nithalian Collektion should know so that it is easier to make the order process online this shop. This is also one of the factors that attracts online shop customers because it makes it easier for customers. The Nithalian Collection also uses hashtags or hashtags according to the items they sell in each of their posts to make it easier for buyers to find the items they want, Makeup that is 
sold at very economical prices, which are sold with prices starting from IDR 65,000 and varied and also to get more. reach those interested in the item. What is even more interesting is that the Nithalian Collection always reviews merchandise in detail in the form of videos and photos on the insta-story, properly and thematically, making customers very interested in the goods they sell and do not hesitate to buy the item because there is already a review.

\section{CONCLUSION}

Internet, which is one of the latest inventions of the era of globalization in the field of information technology, is very beneficial for all people around the world to share information and communicate, including sharing information on products / services being sold. In this very developed era, marketing is not only done by placing advertisements on television, radio or print media, online business marketing is also carried out using new media, namely through social networks or social media, one of which is currently being used by many social media, now is Instagram. , because it has many features and can attract more enthusiasts to 


\section{REFERENCES}

Adinda, S., \& Pangestuti, E. (2019). Pengaruh Media Sosial Instagram @exploremalang terhadap Minat Berkunjung Followers ke Suatu Destinasi (Survei pada Followers @explormalang). Jurnal Administrasi Bisnis (JAB), 72(1), 176-183. http://administrasibisnis.studentjournal.ub.ac.id/index.php/jab/article/view/2852/3239

Asriani, I. A. I., \& Darma, G. S. (2017). Peran Media Sosial Online Dan Komunitas Terhadap Keputusan Nasabah Bank. Jurnal Manajemen Pemasaran, 14(1).

Krisnawati, D. (2018). Peran Perkembangan Teknologi Digital Pada Strategi Pemasaran Dan Jalur Distribusi Umkm Di Indonesia. Jurnal Manajemen Bisnis Krisnadwipayana, 6(1). https://doi.org/10.35137/jmbk.v6i1.175

Nurcahyo, A. (2018). Peran Digital Marketing dan Harga Kompetitif Terhadap Keputusan Berlangganan Indihome. RELEVANCE: Journal of Management and Business, 1(1), 15. https://doi.org/10.22515/relevance.v1i1.1270

Ratnamulyani, I. A., \& Maksudi, B. I. (2018). Peran Media Sosial Dalam Peningkatan Partisipasi Pemilih Pemula Dikalangan Pelajar Di Kabupaten Bogor. Sosiohumaniora, 20(2), 154-161. https://doi.org/10.24198/sosiohumaniora.v20i2.13965

Sari, F., \& Pangestuti, E. (2018). Pengaruh Electronic Word of Mouth (E-Wom) Terhadap Minat Berkunjung dan Keputusan Berkunjung (Studi pada Wisata Coban Rais BKPH Pujon). Jurnal Administrasi Bisnis (JAB), 54(1), 189-196. http://administrasibisnis.studentjournal.ub.ac.id/index.php/jab/article/view/2231 